\title{
On Influence of the Earth's Surface Relief on the Volumes of Overburden at Coal Open Pit Mining with Land-Saving Dumping
}

\author{
Eugeny Kurehin ${ }^{1, *}$, and Mark Hellmer ${ }^{2}$ \\ ${ }^{1}$ T.F. Gorbachev Kuzbass State Technical University, 65000 Kemerovo, 28 Vesennya st., Russian \\ Federation \\ ${ }^{2}$ Imperial College London, SW7 2AZ South Kensington, London, United Kingdom
}

\begin{abstract}
Opencast mining of coal deposits is a priority in Russia, while providing coal to the domestic and foreign markets. Despite reasonable concerns about air pollution and greenhouse gas emissions, coal use will continue to be significant in the future. Consequently, it is necessary to introduce less polluting and more efficient technologies in the industry in the coming decades. Coal deposits are being developed by the open method with a limited deposit length. An indicator for estimating volumes is proposed - the ratio of sediment fraction in a quarry. The dependence of the sediment fraction in the quarry on the pit depth, thickness and angle of incidence of the formation of coal seams (with an oblique and steep fall) is established. Recommendations on the use of land-saving dumping for the open-cast mining of coal deposits have been developed. The structure of complex mechanization on dumping is proposed depending on the properties of rocks (soft or bedrock) and types of transport.
\end{abstract}

\section{Introduction}

Russia has one of the richest coal deposits in the world and is one of the world's leading coal producers and ranks third in the world in coal exports after Australia and Indonesia.

Most of Russia's coal reserves are mainly located in Siberia and the Far East, which creates problems for their commercial development, since it will take a long time to transport them to domestic and foreign markets.

Coal mining in Russia in the future will be $325-430$ million tons. According to the Federal Institute of Sciences and Natural Resources of Germany, Russia accounts for 160 billion tons of coal reserves, which is more than $15 \%$ of world reserves and provides the third largest in the world after the US and China [1].

World reserves of hard coal (that is, reserves for commercial use) are approximately 755 Gt, of which Russia accounts for $69 \mathrm{Gt}(9.1 \%)$. Based on these data, Russia ranks fourth after the United States (29.8\%), China (23.9\%) and India (10.2\%) [1].

Global coal demand will grow for the second year in a row and in 2018, it is projected to remain stable over the next five years, as declines in Europe and North America are

\footnotetext{
*Corresponding author: kev.ormpi@kuzstu.ru
} 
offset by strong growth in India and Southeast Asia, according to the latest International coal energy agency [2].

In India, there is the largest increase in coal production, with a growth rate of $3.9 \%$ per year. Coal mining in China accounts for $14 \%$ of the world's primary energy, the largest in the world. While China accounts for almost half of global coal consumption, its clean air measures are designed to limit the demand for coal in China in the future. Coal demand in China will decline by about $3 \%$.

Air quality and climate policies, coal removal campaigns, phase-out announcements, reduced renewable energy costs and an abundant supply of natural gas put pressure on coal. As a result, the share of coal in the global energy balance is projected to decline slightly from $27 \%$ in 2017 to $25 \%$ by 2023 .

Coal provides a third of all energy used worldwide, and accounts for $38 \%$ of electricity generation, and also plays an important role in industries such as metallurgy [3].

Despite reasonable concerns about air pollution and greenhouse gas emissions, coal use will continue to be significant in the future. Consequently, it is necessary to introduce less polluting and more efficient technologies in industry so that coal becomes a cleaner energy source in the coming decades. The fund of the operating coal-mining enterprises of Russia as of 01/01/2019 has 176 enterprises (mines - 57, open mining - 119) [4].

Coal mining by the open method amounted to 331 million tons. The share of the open method in total production was $75.3 \%$. The volume of overburden operations (2018) amounted to 2261.07 million cubic meters. m (by 312.5 million cubic meters, or $16 \%$ more than in 2017). In 2018, compared to the same period last year, coal production increased in three of the country's four main coal basins: in Kuznetsky - by 14 million tons, or by $6 \%$ (255.3 million tons), 1.9 million tons, or 5\% (40.3 million tons were produced) and in Pechora - by 1 million tons, or $11 \%$ (10 million tons were mined). The decline was noted in the Donetsk coal basin - by 0.5 million tons, or $8 \%$ (5.3 million tons were mined) [4].

The annual coal production in Russia by coal companies in 2018 amounted to 12-110 million tons. As part of coal companies with small production capacity cuts, their total annual production amounted to 10.4 million tons (Table 1).

Table 1. Annual production capacity of coal mines in Russia (as part of coal companies).

\begin{tabular}{|c|c|c|}
\hline No & Name & $\begin{array}{c}\text { Production capacity } \\
\text { of open mining, } \\
\text { million tons annually }\end{array}$ \\
\hline JSC "SUEK" \\
\hline 1 & Kansky razrez JSC (Krasnoyarsk Territory) & 0.177 \\
\hline 2 & AO "Razrez Izykhsky" (Republic of \\
Khakassia) & 1.370 \\
\hline 3 & Chita Ugol LLC (Zabaykalsky Krai) & 1.323 \\
\hline 4 & LLC "Arctic razrabotki Zabaykalsky Krai) & 0.619 \\
\hline \multicolumn{3}{|c|}{ AO HK «SDS-Ugol» } \\
\hline 5 & JSC "Prokopievsky ugolny razrez" \\
\hline \multicolumn{3}{|c|}{ LLC EvrazHolding } \\
\hline 6 & LLC "Management Company" \\
Mezhegeyugol" & 1.678 \\
\hline \multicolumn{3}{|c|}{ En+ Group } \\
\hline 7 & LLC "Tuvinsk GRK" \\
\hline 8 & LLC "Razrez Nygdinsky" & 0.656 \\
\hline \multicolumn{3}{|c|}{ JSC "Russky Ugol" } \\
\hline 9 & Sayano-Partizansky LLC \\
\hline \multicolumn{3}{|c|}{ ZAO Strojservis } \\
\hline 10 & LLC JV "Barzassky tovarishestvo" & 1.029 \\
\hline 11 & AO "Razrez Shestaki" & 1.760 \\
\hline
\end{tabular}




\section{Materials and Methods}

Mining and geological conditions of coal deposits in Russia are represented by suites of coal seams of low and medium thickness, less often powerful [5]. The thickness of loose sediments (sediment) varies from 3 to $60 \mathrm{~m}$.

In the Kuznetsk coal basin is mainly represented by coal layers of low and medium power (from 82 to $88 \%$ ), thick layers (more than $10 \mathrm{~m}$ ) $12-18 \%$.

Coal deposits mined by small open-pit fields are distinguished by the following features:

- on a relief (flat, hilly, a height with a tilt angle of a terrestrial surface and others);

- by position relative to the dominant level of the surface and depth of occurrence (surface 20-30 and depth type 31-100 m);

- on the power of coal seams (very low, low and medium power);

- the angle of incidence (horizontal, gentle, sloping, steep);

- the location of the quarries (local, peripheral, group);

- by the volume of rock mass in the quarry (overburden up to 100 million m3; coal reserves up to 50 million tonnes);

- according to the geometrical parameters of the quarry (length and width up to $2.0 \mathrm{~km}$, depth up to $100 \mathrm{~m}$ );

- the ratio of the volume of rock mass in the quarry (the share of sediment, bedrock, geological reserves of coal).

With the open development of coal deposits oblique and steep fall using a longitudinal one and two on-board development systems, the entire rock is removed to external dumps. When grouping mountain areas, when the distances between the quarry fields do not exceed 2-4 km, subsoil users need, firstly, to work out the areas consistently, with the possibility of using adjacent areas [6] for storing overburden, and secondly, to use technology with earth-saving dumping.

\section{Results and Discussion}

The analysis showed that in open-pit mining mainly deep-longitudinal development systems $(82.1 \%)$ are used, followed by placement of overburden on external dumps and continuous development systems $(17.9 \%)$ with partial internal dumping.

Consequently, most of the overburden with open pit mining will be located on external dumps, which will require withdrawal of land resources.

To increase the efficiency of open pit mining of steep and steep deposits, the following types of dumping should be used:

- internal (within the boundaries of the mining allotment);

- external (single and multi-level dumping);

- land-sparing (in open pit mining of the adjacent plot) [6].

When choosing a complex of mining equipment, the following recommendations are guided [11]:

- the complex of equipment should include only cars, passport characteristics, which correspond to the mining and technological characteristics of rocks;

- the complex of equipment must comply with the adopted systems of development and opening, the size and shape of the quarry, its capacity, the period of construction and operation, and the organizational conditions for conducting mining operations.

On the basis of the proposed classification features of career fields, small career fields include: geological (reserves, thickness and number of coal seams, share of sediment thickness, angle of incidence of coal seams), geometric (depth and length of the career field) and technological (cycling equipment, road transport). 
To estimate the volumes of overburden, a method has been developed for calculating the areas and volumes of elements of the quarry field, which allows determining the area of mining allotment and quarry mining.

The volume of overburden in the career field is determined by the expression:

$$
V_{\mathrm{v}}=V_{\mathrm{n}}+V_{\mathrm{k}}
$$

where $V \mathrm{n}$ - the volume of sediment, $\mathrm{m}^{3} ; V \mathrm{k}$ - the volume of bedrock in the carbonless and coal-saturated zone, $\mathrm{m}^{3}$.

Considering the sediment thickness, which in a small open pit field will have a higher proportion compared to a large open pit field, it is necessary to determine a coefficient that takes into account the share of sediment in the total volume of overburden.

The ratio of the share of sediment in a career, is determined by the expression:

$$
K_{\mathrm{n}}=\frac{V_{\mathrm{n}}}{V_{\mathrm{n}}+V_{\mathrm{k}}}
$$

With open pit mining of steep and steep deposits, the volume of overburden rocks in a small open pit field is 5.60-85.88 million $\mathrm{m}^{3}$. The coefficient of the share of sediment in the open pit is: $0.30-0.79\left(H_{\mathrm{k} . \mathrm{k}}=40 \mathrm{~m}\right), 0.22-0.55\left(H_{\mathrm{k} . \mathrm{k}}=60 \mathrm{~m}\right), 0.21-0.65\left(H_{\mathrm{k} . \mathrm{k}}=80 \mathrm{~m}\right), 0.15-$ $0.60\left(H_{\mathrm{k} . \mathrm{k}}=100 \mathrm{~m}\right)($ Table 2$)$.

\begin{tabular}{|c|c|c|c|c|c|c|c|}
\hline \multirow{2}{*}{$\begin{array}{c}\boldsymbol{H}_{\mathrm{k} . \mathrm{k}}, \\
\mathrm{m}\end{array}$} & \multirow{2}{*}{$\begin{array}{c}\varphi, \\
\text { deg. }\end{array}$} & \multirow{2}{*}{$\begin{array}{c}m_{\mathrm{H}}, \\
\mathbf{m}\end{array}$} & \multirow{2}{*}{$\begin{array}{c}\text { Surface } \\
\text { relief }\end{array}$} & \multicolumn{3}{|c|}{ Overburden volume, mln.m ${ }^{3}$} & \multirow{2}{*}{$\begin{array}{c}\text { The coefficient of } \\
\text { the share of } \\
\text { sediments } K_{n} \text {, units }\end{array}$} \\
\hline & & & & $V_{H}$ & $V_{\mathrm{K}}$ & $V_{\mathbf{B}}$ & \\
\hline \multirow{12}{*}{40} & \multirow{6}{*}{20} & \multirow{3}{*}{10} & tilt up & 5.97 & 5.57 & 11.54 & 0.52 \\
\hline & & & horizontal & 3.95 & 8.48 & 12.42 & 0.32 \\
\hline & & & slope down & 5.81 & 13.66 & 19.47 & 0.30 \\
\hline & & \multirow{3}{*}{30} & tilt up & 20.54 & 5.57 & 26.10 & 0.79 \\
\hline & & & horizontal & 13.47 & 8.48 & 21.94 & 0.61 \\
\hline & & & slope down & 19.03 & 13.66 & 32.69 & 0.58 \\
\hline & \multirow{6}{*}{80} & \multirow{3}{*}{10} & tilt up & 2.24 & 4.26 & 6.49 & 0.34 \\
\hline & & & horizontal & 1.95 & 3.90 & 5.85 & 0.33 \\
\hline & & & slope down & 1.85 & 3.75 & 5.60 & 0.33 \\
\hline & & \multirow{3}{*}{30} & tilt up & 7.80 & 4.26 & 12.05 & 0.65 \\
\hline & & & horizontal & 6.84 & 3.90 & 10.75 & 0.64 \\
\hline & & & slope down & 6.63 & 3.75 & 10.38 & 0.64 \\
\hline \multirow{12}{*}{60} & \multirow{6}{*}{20} & \multirow{3}{*}{10} & tilt up & 7.16 & 9.83 & 16.99 & 0.42 \\
\hline & & & horizontal & 5.05 & 15.51 & 20.56 & 0.25 \\
\hline & & & slope down & 6.99 & 24.59 & 31.58 & 0.22 \\
\hline & & \multirow{3}{*}{30} & tilt up & 24.25 & 9.83 & 34.08 & 0.71 \\
\hline & & & horizontal & 16.89 & 15.51 & 32.39 & 0.52 \\
\hline & & & slope down & 22.68 & 24.59 & 47.27 & 0.48 \\
\hline & \multirow{6}{*}{80} & \multirow{3}{*}{10} & tilt up & 3.00 & 8.24 & 11.24 & 0.27 \\
\hline & & & horizontal & 2.63 & 7.58 & 10.21 & 0.26 \\
\hline & & & slope down & 2.48 & 7.24 & 9.72 & 0.26 \\
\hline & & \multirow{3}{*}{30} & tilt up & 10.18 & 8.24 & 18.42 & 0.55 \\
\hline & & & horizontal & 8.94 & 7.58 & 16.52 & 0.54 \\
\hline & & & slope down & 8.58 & 7.24 & 15.82 & 0.54 \\
\hline \multirow{2}{*}{80} & \multirow{2}{*}{20} & \multirow{2}{*}{10} & tilt up & 8.43 & 15.12 & 23.55 & 0.36 \\
\hline & & & horizontal & 6.23 & 24.51 & 30.74 & 0.20 \\
\hline
\end{tabular}

Table 2. Parameters and indicators for open pit mining. 


\begin{tabular}{|c|c|c|c|c|c|c|c|}
\hline & & & slope down & 8.25 & 38.40 & 46.64 & 0.18 \\
\hline & & & tilt up & 28.19 & 15.12 & 43.32 & 0.65 \\
\hline & & 30 & horizontal & 20.53 & 24.51 & 45.04 & 0.46 \\
\hline & & & slope down & 26.56 & 38.40 & 64.96 & 0.41 \\
\hline & & & tilt up & 3.82 & 13.54 & 17.37 & 0.22 \\
\hline & & 10 & horizontal & 3.35 & 12.48 & 15.82 & 0.21 \\
\hline & & & slope down & 3.15 & 11.88 & 15.03 & 0.21 \\
\hline & 80 & & tilt up & 12.73 & 13.54 & 26.27 & 0.48 \\
\hline & & 30 & horizontal & 11.19 & 12.48 & 23.66 & 0.47 \\
\hline & & & slope down & 10.68 & 11.88 & 22.56 & 0.47 \\
\hline & & & tilt up & 9.77 & 21.50 & 31.26 & 0.31 \\
\hline & & 10 & horizontal & 7.48 & 35.56 & 43.04 & 0.17 \\
\hline & 20 & & slope down & 9.58 & 55.21 & 64.79 & 0.15 \\
\hline & 20 & & tilt up & 32.37 & 21.50 & 53.87 & 0.60 \\
\hline & & 30 & horizontal & 24.41 & 35.56 & 59.97 & 0.41 \\
\hline 100 & & & slope down & 30.67 & 55.21 & 85.88 & 0.36 \\
\hline 100 & & & tilt up & 4.70 & 20.22 & 24.92 & 0.19 \\
\hline & & 10 & horizontal & 4.12 & 18.64 & 22.76 & 0.18 \\
\hline & 80 & & slope down & 3.87 & 17.71 & 21.59 & 0.18 \\
\hline & 00 & 30 & tilt up & 15.44 & 20.22 & 35.66 & 0.43 \\
\hline & & & horizontal & 13.58 & 18.64 & 32.22 & 0.42 \\
\hline & & & slope down & 12.90 & 17.71 & 30.62 & 0.42 \\
\hline
\end{tabular}

Note. The length of the career field in terms of $1.0 \mathrm{~km}$. The angle of the earth's surface is 10 degrees.

Depending on the thickness of the sediment $(10-30 \mathrm{~m})$, the depth of the open pit by bedrock (40-100 m) and the slope of the earth's surface, the following expressions are established:

- horizontal relief

$$
\mathrm{K}_{n}=\left(0.0915 \mathrm{~m}_{n}+0.755\right) \mathrm{H}_{k . k}^{-0.46}
$$

- tilt up

slant fall

$$
\mathrm{K}_{n}=3.35 \mathrm{H}_{k . k}^{-\left(-0.0063 \mathrm{~m}_{n}+0.5675\right)}
$$

steep fall

$$
\mathrm{K}_{n}=3.35 \mathrm{H}_{k . k}^{-\left(-0.0083 \mathrm{~m}_{n}+0.7005\right)}
$$

- slope down

slant fall

$$
\mathrm{K}_{n}=3.35 \mathrm{H}_{k . k}^{-\left(-0.009 \mathrm{~m}_{n}+0.75\right)}
$$

steep fall

$$
\mathrm{K}_{n}=3.35 \mathrm{H}_{k . k}^{-\left(-0.0087 \mathrm{~m}_{n}+0.72\right)}
$$

where $H_{\text {k.k }}$ - pit depth by bedrock, m; $m_{H}$ - sediment thickness, $\mathrm{m}$.

The accuracy of the approximation is $\mathrm{R}^{2}=98-99 \%$. 
In open-pit mining, electric excavators, mechlopats, hydraulic excavators and wheel loaders from well-known foreign manufacturers are used: Komatsu, Caterpillar, Liebherr, Hyundai, etc., with a bucket capacity of $0.3-19 \mathrm{~m}^{3}$ and a large unit capacity of $20-56 \mathrm{~m}^{3}$.

For transportation of overburden and coal, dump trucks BelAZ, MAZ, Komatsu, Caterpillar, Hitachi, Terex, Scania, Volvo and others are used, with a lifting capacity of 5100 and $110-450$ tons.

Applied equipment on external dumps and technology of mining and technical reclamation of dumps is directly dependent on the type of overburden, dump equipment (dragline excavators, bulldozers, etc.) and technological schemes.

In order to increase the efficiency of open-pit mining of coal deposits, a technological classification of equipment complexes for mining limited deposits has been developed.

In accordance with the above classification, the following mining equipment complexes are proposed (Table 3 ).

Table 3. Structure of complex mechanization on dumping.

\begin{tabular}{|c|c|c|}
\hline $\begin{array}{c}\text { Type of } \\
\text { rocks }\end{array}$ & Dump equipment & Type of transport \\
\hline Soft & $\begin{array}{c}\text { rope shovel } \\
\text { dragline } \\
\text { hydraulic excavator } \\
\text { (shovel and backhoe) } \\
\text { bulldozer }\end{array}$ & $\begin{array}{c}\text { Automobile, } \\
\text { conveyor, cantilever } \\
\text { spreader }\end{array}$ \\
\hline Hard & $\begin{array}{c}\text { rope shovel } \\
\text { dragline } \\
\text { hydraulic excavator } \\
\text { (shovel and backhoe) } \\
\text { bulldozer }\end{array}$ & $\begin{array}{c}\text { Automobile conveyor, } \\
\text { railway, cantilever } \\
\text { spreader }\end{array}$ \\
\hline
\end{tabular}

\section{Conclusion}

An indicator for estimating volumes is proposed - the ratio of the share of sediment in a quarry, which must be considered when designing open-pit mining sites: $0.30-0.79$ (Hk.k $=$ $40 \mathrm{~m}) .0 .22-0.55(H \mathrm{k} . \mathrm{k}=60 \mathrm{~m}), 0.21-0.65(H \mathrm{k} . \mathrm{k}=80 \mathrm{~m}), 0.15-0.60(H \mathrm{k} . \mathrm{k}=100 \mathrm{~m})$. As a result of the interrelation of the depth of the quarry field (by bedrock). the angle of incidence of the coal seam suite, the slope of the earth's surface (consonant, horizontal, inconsistent relief), sediment thickness, sediment volumes and bedrocks, the sediment ratio in the quarry was obtained. It is necessary to take into account the division of a small quarry field into zones, the volume of bedrock is determined depending on the depth (40$100 \mathrm{~m}$ ), length, change of relief and angle of inclination of the earth's surface (by 10 degree), increases in the zone by $5-46 \%$ (slope down) and decreases by $3-62 \%$ (tilt up). The structure of complex mechanization on dumping, it is necessary to choose depending on the properties of rocks (soft or bedrock) and types of transport.

\section{References}

1. Coal base of Russia. Coal basins and deposits of Western Siberia (Geoinformcenter LLC, Moscow, 2003)

2. E.V. Kourekhin, News of Tomsk Polytechnic University. Georesource engineering, 5, 67-82 (2017) 
3. V.S. Kovalenko, V.B. Artemyev, P.I. Opanasenko, Earth-saving and land-reproducing technologies on coal mines (Mining" LLC, Moscow, 2013)

4. V.I. Cheskidov, The sequence of mining flat and sloping coal seams with the placement of overburden in the internal dumps (Abstract, Novosibirsk, 1999)

5. V.G. Pronoza, A.I. Koryakin, S.M. Darling, Bulletin of KuzSTU, 4, 3-7 (2002)

6. G.G. Sakantsev, Geotechnological foundations of internal dumping during the development of deep-lying deposits of limited length (ETSU, Ekaterinburg, 2012)

7. V.V. Rzhevsky, Open pit mining (Nedra, Moscow, 1985)

8. E.V. Kourekhin Mining Information and Analytical Bulletin, 10, 519-535 (2015)

9. E.V. Kourekhin, On the question of the assembly of excavation and loading equipment for the development of inclined and steep coal deposits with small open pits (KuzSTU, Kemerovo, 2010)

10. Hitachi, Coal Age, 117:5, 56 (2012)

11. P. Jonson, Coal Age, 117:2, 29-33 (2012) 